\title{
Integrated Development Model (IMD): A Systematic Review and Reflection
}

\author{
Jordan Tovera Salvador, PhD, RN \\ University of Dammam, Kingdom of Saudi Arabia
}

doi: 10.19044/esj.2016.v12n19p244 URL:http://dx.doi.org/10.19044/esj.2016.v12n19p244

\begin{abstract}
This paper evaluates a recognized supervision model and reflects on how this model has affected one's personal role as an instructional supervisor. Integrated Development Model of Supervision (IMD) is one of the most sought after developmental models of supervision in the past decades and even up to the present. Developmental models of supervision are usually derived from the idea that the supervisee has the capability to develop from novice to expert with the guidance and counseling of the supervisor. Each of the developmental stages of supervision has specific skills and competencies that are notable and observable amongst the supervisee and supervisor. However, just like any other models of supervision, developmental models have loopholes identified by experts such as: (1) these models are simplistic and vague, (2) emphasizing on the amalgamation of the advances to developmental supervisions, (3) no new models of supervision have emerged, (4) does not allow differing routes to development for dissimilar trainees and (5) does not report any waning on the part of the supervisee. IDM was formulated based from the ambiguities of the early developmental models and to answer the gaps in shifting between each developmental stage.
\end{abstract}

Keywords: Autonomy, Developmental Models, Integrated Development Model of Supervisions, Motivation, Self-Awareness

\section{Introduction:}

This paper evaluates a recognized supervision model and reflects on how this model has affected one's personal role as an instructional supervisor particularly the Integrated Development Model of Supervision. It is one of the most researched developmental models of supervisions nowadays due to its research ability and application in various filed like in health care services and social sciences. The aims and objectives of this paper can be summarized as follows: 
1. Delineate fundamental terminologies related to developmental models of supervision (remember).

2. Abridge the related literature pertaining IDM (understand).

3. Outline through a table the levels and stages of IDM depicted by the three structures: self-awareness (cognitive/affective), motivation and autonomy (apply).

4. Compare and contrast the different levels and stages of IDM (analyze).

5. Convoke reflection in terms of new learning, application, and challenges (evaluate).

6. Formulate a conclusion regarding IDM (create).

\section{Systematic Review}

Developmental model of supervision had been the apple of the eye of researchers since 1980s. In fact, these models were arched in the dogma that human beings are capable to learn specific skills and competencies through the supervision of an expert across the four levels of development from novice to master professional. A supervisor can observe the development of his supervisees based from what is expected from each domain of learning. Foundational concepts of these models of supervision were constructed from these two assumptions based from the ideologies of Chagnon and Russell (1995):

1. The supervisees partake series of stages/levels that are distinctively vary from each other and results acquisitions of new skills and competencies.

2. Every stage/level should have assortments of supervisory techniques and methods to effectively and efficiently guide the supervisees.

Over the years, there were a lot of developmental models of supervision have been available. Some of the notable models known were Littrell, Lee-Borden \& Lorenz Model (1979), which is an archetypal that endeavored to match the behavior of the supervisor exactly what the supervisee's development needed; Stoltenberg \& Delworth Model (1987), which came from the idea of Stoltenberg (1981) and some essential features from Loganbill, Hardy and Delworth Model (1982), tackled the three levels of the supervisee's development, eight levels of dimensions and the three structures propositioned to track the progress of the supervisees on each of the eight dimensions; and Skovholt \& Ronnestad Model (1992), which was a longitudinal qualitative study that focused both on the supervisees; and supervisors' development remains and continues throughout the lifespan.

People believed that these models could be suitable framework for their respective settings. Nevertheless, some scholars criticized these models 
due to its theoretical shortcomings like the following reasons: (1) these models are simplistic and vague (Russell et al, 1984); (2) emphasizing on the amalgamation of the advances to developmental supervisions (Russell et al, 1984), (3) no new models of supervision have emerged (Holloway, 1992); (4) does not allow differing routes to development for dissimilar trainees (Stoltenberg \& Delworth, 1987); (5) does not report any waning on the part of the supervisee (Bernard \& Goodyear, 1992); (6) the transition of among the stages is questionable due to lack of concrete evidence how to get into it because it foci are more on the models per se (Worthington, 1987); and (7) it bestows partial methods and techniques in each level of supervision (Haynes et al, 2003).

These were the reasons why scholars have been eager to explore - to mitigate these shortcomings and modify the previously developmental models to satisfy the needs of the individuals. The latest version of Stoltenberg, McNeill, and Delworth's Integrated Development Model of Supervision (1997), which had been popular due to its descriptive in the foundations of the supervisee per level of development and at same time discusses each level's prescriptive supervisory interventions that were lacking in the previous early developmental models, tried to alleviate the loopholes and shortcomings of the early development models of supervision. An anonymous author from the Adolescence journal stated that: 'Stoltenberg et al (1997) indicated in their book that IDM is a proven and adaptable model for supervising therapists at all levels of experience across disciplines and therapeutic orientations' (p. 185).

IDM has four levels that a supervisee should partake and fulfill (Stoltenberg et al, 1997). These levels diverge from being a novice to master professional, thus, have distinctive skills and competencies that are discoverable along the process of supervision. A newly staff nurse hired in a hospital is a best-fit example for these levels. A staff nurse who just landed the job is considered to be a novice due to unfamiliarity in the bylaws, protocols, policies and procedures of the institution, nevertheless, training and development activities are provided to orient the staff nurse to blend in with the organization. As time goes by, the staff nurse will be accustomed with the presented organizational climate and environment. The role of the supervisor in the scenario is to supervise the needs of the supervisee in terms of developmental learning. Moreover, the supervisor can be the coordinator of the unit, unit managers and administrators of the department or institution. Likewise, the supervisors employ several methods and strategies appropriately to the level of the supervisees. In the beginning phase of the supervision process, the supervisor must be patiently seeking assistance to the supervisee until such time familiarization and adaptation take place. 
It should be taken into consideration that when a supervisee faces new confronts in their professional pursuits, the supervisee may always go back to the prior stages to approach the encounter. This is why levels are characterized according to three structures namely 'self-other awareness (cognitive/affective), motivation and autonomy' (Stoltenberg \& Delworth, 1997). Likewise, these three levels serve as the markers to assess development across the different domains. Self-other awareness denotes the awareness level in relation to the supervisee's counseling skills and behaviors, similarly, accepting the biosphere of the clientele. Motivation converges and yearns to employ in training activities that could develop them to better professionals. Furthermore, 'Autonomy is the degree of independence the supervisee exhibits' (Stoltenberg \& Delworth, 1997).

\begin{tabular}{|c|c|c|c|c|}
\hline Level & Overview of Stage & Self-Other Awareness & Motivation & Autonomy \\
\hline Level 1 & $\begin{array}{l}\text { Limited training or } \\
\text { experience in the specific } \\
\text { domain of supervision (i.e. } \\
\text { treatment planning, case } \\
\text { conceptualization, etc.) }\end{array}$ & \begin{tabular}{|l|} 
High levels of self-focus, \\
with little self-evaluation, \\
anxiety related to evaluation \\
by supervisor, concerned \\
with "doing it right"
\end{tabular} & $\begin{array}{l}\text { Motivation and anxiety are } \\
\text { focused on acquisition of } \\
\text { skills. Want to know the } \\
\text { "correct" approach to working } \\
\text { with clients }\end{array}$ & \begin{tabular}{|l|} 
Very dependent upon \\
supervisor, requires high \\
levels of structure, positive \\
reinforcement. Unable to \\
tolerate direct confrontation \\
\end{tabular} \\
\hline Level 2 & $\begin{array}{l}\text { Transitioning for high levels } \\
\text { of dependence and imitative } \\
\text { forms of counseling. } \\
\text { Beginning to respond to the } \\
\text { highly structured supervisory } \\
\text { practices of Level } 1 \text {. This } \\
\text { usually occurs after two to } \\
\text { three semesters of } \\
\text { supervised work. }\end{array}$ & $\begin{array}{l}\text { Increased ability to focus on } \\
\text { client and exhibit empathy. } \\
\text { Still struggles with balancing } \\
\text { focus on self and client. May } \\
\text { become confused and } \\
\text { enmeshed with client }\end{array}$ & $\begin{array}{l}\text { Fluctuates between high } \\
\text { levels of confidence, feelings } \\
\text { of incompetence, and } \\
\text { confusion }\end{array}$ & $\begin{array}{l}\text { Vacillates between autonomy } \\
\text { and dependence. This may } \\
\text { manifest in the form of } \\
\text { resistance }\end{array}$ \\
\hline Level 3 & $\begin{array}{l}\text { Beginning to develop a } \\
\text { personalized approach to } \\
\text { counseling. Understands } \\
\text { and utilizes "self" in therapy. }\end{array}$ & $\begin{array}{l}\text { A different type of self } \\
\text { awareness emerges. } \\
\text { Demonstrates the ability to } \\
\text { stay focused on client while } \\
\text { attending to personal } \\
\text { reactions and responses to } \\
\text { client. This ability is utilized } \\
\text { in decision-making about the } \\
\text { client }\end{array}$ & $\begin{array}{l}\text { Consistent as confidence } \\
\text { increases, may still exhibit } \\
\text { some self-doubt, but the } \\
\text { doubt has less impact on } \\
\text { ability to proceed }\end{array}$ & $\begin{array}{l}\text { Solid belief in own judgment, } \\
\text { and skills. Supervision } \\
\text { becomes more of a } \\
\text { consultant and increase } \\
\text { collegiality is exhibited }\end{array}$ \\
\hline $\begin{array}{l}\text { Level } 3 \mathrm{i} \\
\text { (Integrated }\end{array}$ & \multicolumn{4}{|c|}{$\begin{array}{l}\text { The supervisee has reached Level } 3 \text { across multiple domains. A personal style of counseling has emerged and the } \\
\text { supervisee demonstrates high levels of awareness regarding personal competency. }\end{array}$} \\
\hline
\end{tabular}

Table 1. Level of Integrated Development Model of Stolenberg, McNeill and Delworth (1987). https://www.txca.org/images/tca/TheoriesofSupervision/TheoriesofSupervision9.html

With the three intervening markers, self-other awareness (cognitive and affective), motivation and autonomy, to assess development of the supervisee, eight domains are observed at each level (Stoltenberg and Delworth, 1987):

- Interventions skills competence - self-reliance to participate in 'therapeutic interventions';

- Assessment techniques - managing and directing psychological assessments;

- Interpersonal assessment - exercising individual skills for the sake of client's concerns; 
- Client conceptualization - understanding the totality of the clientele;

- Individual differences - competence in dealing with sociocultural differences such as race, ethnicity, gender preferences, etc.

- Theoretical orientation - understanding theory;

- Treatment plans and goals - determination of suitable interventions for envisaged goals and objectives; and

- Professional ethics - integration of professional and personal ethics.

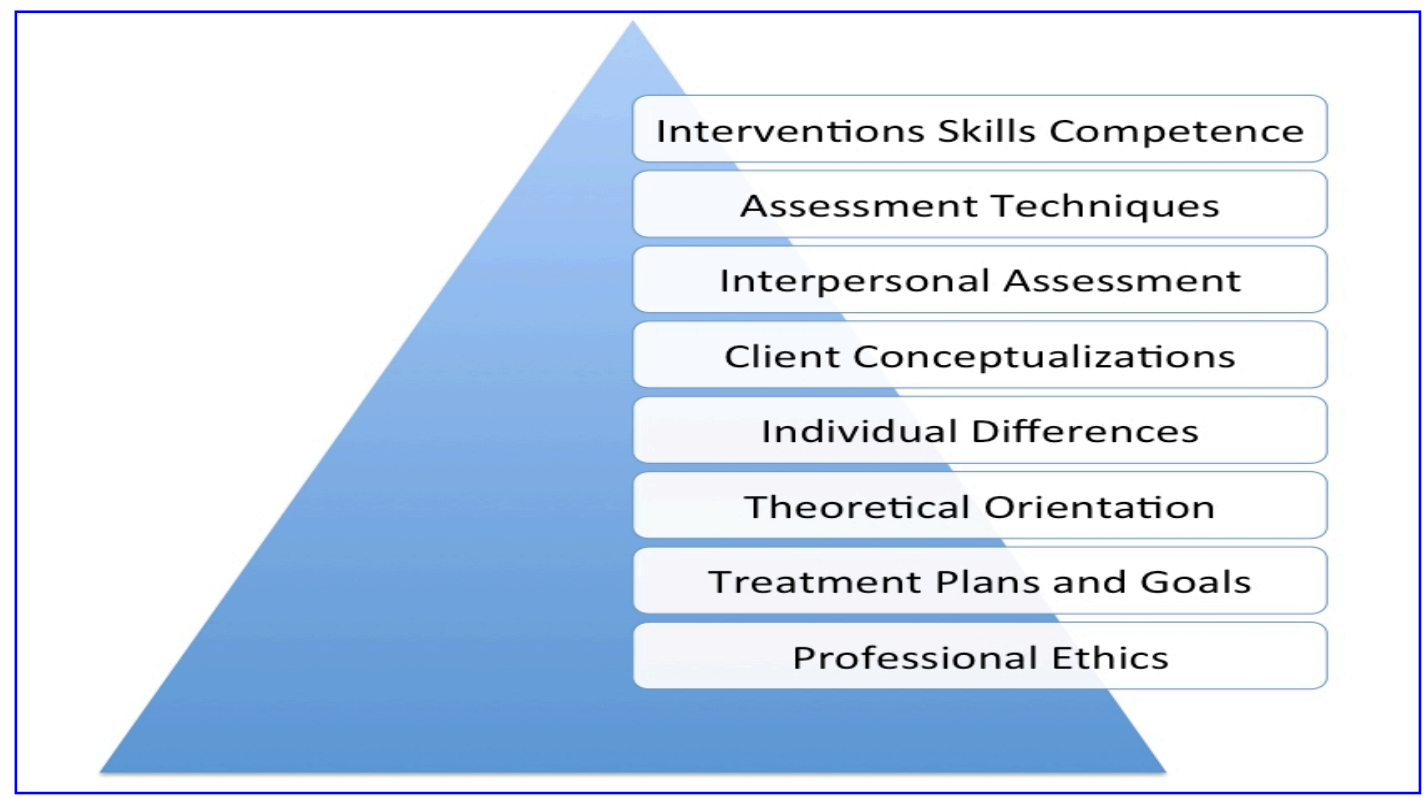

Figure 1. Eight Domains of Professional Activity (Strolenberg, McNeill and Helworth, 1987)

Integrated Development Model of Supervision (IDM) emphases on the journey of the supervisee's personal and professional and the strategies, interventions and mechanisms commissioned by the supervisor across the level of development from supervisee's novice status to master professional. The table 2 below shows the matrix of the IDM level to the structures expected from supervisees, client assignment, and supervisor's strategies, interventions and mechanisms. Adapted from the IDM of Supervision (Stoltenberg, 1988; McNeill et al., 1992; Stoltenberg, 1993; Stoltenberg \& McNeill, 2010). 


\begin{tabular}{|c|c|c|c|c|c|}
\hline IDM Level & $\begin{array}{c}\text { Supervisee Characteristics } \\
\text { (Motivation, Autonomy, } \\
\text { and Awareness) }\end{array}$ & $\begin{array}{c}\text { Client } \\
\text { Assignment }\end{array}$ & $\begin{array}{l}\text { Supervisor } \\
\text { Strategies }\end{array}$ & Interventions & $\begin{array}{l}\text { Supervisory } \\
\text { Mechanisms }\end{array}$ \\
\hline $\begin{array}{c}1 \\
\text { "Novice" }\end{array}$ & $\begin{array}{l}\text { - } \text { High motivation } \\
\text { dimited autonomy with } \\
\text { supendency on the } \\
\text { - Primary focus on } \\
\text { him/herself } \\
\text { - Anxious (e.g., due to } \\
\text { working in a new area } \\
\text { or due to the process of } \\
\text { being evaluated) }\end{array}$ & $\begin{array}{l}\text { Mild Presenting } \\
\text { Problems or } \\
\text { Maintenance } \\
\text { Cases }\end{array}$ & $\begin{array}{l}\text { - Provides } \\
\text { structure } \\
\text { - Encourages } \\
\text { risk taking as } \\
\text { autonomy } \\
\text { grows } \\
\text { - Act as an } \\
\text { expert role } \\
\text { model }\end{array}$ & $\begin{array}{l}\text { - Facilitative } \\
\text { - Prescriptive } \\
\text { - Conceptual } \\
\text { - Catalytic }\end{array}$ & $\begin{array}{l}\text { - Observation } \\
\text { - Skills Training } \\
\text { - Role Playing } \\
\text { - Interpret Dynamics } \\
\text { - Reading } \\
\text { - Group Supervision } \\
\text { - Appropriate Balance } \\
\text { of Ambiguity } \\
\text { - Address Stress, then } \\
\text { Weaknesses } \\
\text { - Closely Monitors } \\
\text { Clients }\end{array}$ \\
\hline 2 & $\begin{array}{l}\text { Fluctuating motivation } \\
\text { - high when } \\
\text { confidence is high, but } \\
\text { low when confusion or } \\
\text { when negative affect is } \\
\text { experienced }\end{array}$ & $\begin{array}{l}\text { More difficult } \\
\text { clients with } \\
\text { more severe }\end{array}$ & $\begin{array}{l}\text { - More } \\
\text { facilitative and } \\
\text { less didactic }\end{array}$ & $\begin{array}{l}\text { - Facilitative } \\
\text { - Prescriptive } \\
\text { - Conceptual }\end{array}$ & $\begin{array}{l}\text { - Observation } \\
\text { - Role Playing } \\
\text { - Interpret Dynamics }\end{array}$ \\
\hline
\end{tabular}

\begin{tabular}{|c|c|c|c|c|c|}
\hline & $\begin{array}{l}\text { - Striving for more } \\
\text { autonomy } \\
\text { - Dependency-autonomy } \\
\text { conflict } \\
\text { - Focuses more on the } \\
\text { emotional and } \\
\text { cognitive experiences } \\
\text { of the consultec }\end{array}$ & $\begin{array}{l}\text { presenting } \\
\text { problems }\end{array}$ & $\begin{array}{l}\text { - Encourages } \\
\text { more autonomy } \\
\text { - Supports } \\
\text { affective } \\
\text { reactions }\end{array}$ & $\begin{array}{l}\text { - Confrontive } \\
\text { - Catalytic }\end{array}$ & $\begin{array}{l}\text { - Group Supervision } \\
\text { - Broaden Clientele }\end{array}$ \\
\hline 3 & $\begin{array}{l}\text { Fluctuations in } \\
\text { motivation diminish; } \\
\text { and the individual } \\
\text { exhibits more constant } \\
\text { behavior } \\
\text { - Greater understanding } \\
\text { of self strengths and } \\
\text { weaknesses and } \\
\text { exhibits greater } \\
\text { autonomy } \\
\text { Heightened self- and } \\
\text { other-awareness and is } \\
\text { better able to gauge the } \\
\text { emotional impact of } \\
\text { others } \\
\text { Deep knowledge and } \\
\text { integration of learning } \\
\text { Here supervision } \\
\text { becomes more of a } \\
\text { consultation with more } \\
\text { collegial sharing } \\
\text { (rather than intensive } \\
\text { guidance and advice) }\end{array}$ & & $\begin{array}{l}\text { - Focus on } \\
\text { personal and } \\
\text { professional } \\
\text { integration } \\
\text { - Supports } \\
\text { development of } \\
\text { professional } \\
\text { identity } \\
\text { Helps support } \\
\text { consistency in } \\
\text { development } \\
\text { Development } \\
\text { of a } \\
\text { consultation } \\
\text { relationship } \\
\text { with less } \\
\text { evaluation }\end{array}$ & $\begin{array}{l}\text { - Facilitative } \\
\text { - Confrontive } \\
\text { - Conceptual } \\
\text { - Catalytic }\end{array}$ & $\begin{array}{l}\text { - Peer Supervision } \\
\text { - Group Supervision } \\
\text { - Strive for Integration }\end{array}$ \\
\hline $\begin{array}{c}3 \mathrm{i} \\
\text { "Master } \\
\text { Professional" }\end{array}$ & $\begin{array}{l}\text { - Demonstrates personal } \\
\text { autonomy } \\
\text { - Insightful awareness } \\
\text { - Develops integration } \\
\text { across domains } \\
\text { - Can confront personal } \\
\text { and professional issues }\end{array}$ & & $\begin{array}{l}\text { - Less structured } \\
\text { environment } \\
\text { - The trainee } \\
\text { functions and } \\
\text { thinks more } \\
\text { independently }\end{array}$ & $\begin{array}{l}\text { - Facilitative } \\
\text { - Confrontive } \\
\text { - Conceptual } \\
\text { - Catalytic }\end{array}$ & $\begin{array}{l}\text { - Peer Supervision } \\
\text { - Group Supervision } \\
\text { - Strive for Integration }\end{array}$ \\
\hline
\end{tabular}

Table 2: The changing characteristics of supervisees as they journey through, and across career levels, and that the strategies that supervisors employ to support these 


\section{Reflection}

IDM is one of the most interesting, talked about, likewise, most researched models of developmental supervision due to its descriptive and prescriptive nature. Descriptive in the sense that supervisee's levels of development are well described and outlined. In fact, characteristics, skills and competencies are already expected per level. Prescriptive in nature because interventions employed in the supervisory process are appropriately planned and standardized according to each levels of development.

The main gist of development models of supervision based from Hayes, Courey \& Moulton (2003) is to develop the supervisee into an improved professional having excellent problem solving skills and reflective on the entire process of supervision and counseling. From the novice status of an individual with limited knowledge and skills needs guidance and counseling from an expert/supervisor in a particular field to get orientation and familiarization with the bylaws, protocols, policies and procedures of their respective institutions. A supervisor, on the other hand, must balance the knowledge and skills suitable to communicate with the supervisee's level. At this stage, supervisor must be supportive, appreciative and prescriptive to let the supervisee to feel comfortable, relaxed and soundminded during the entire process of supervision. In regards to the three structural markers, level 1 is more heightened compared to the rest of the developmental levels. Novice individuals have high motivation, limited autonomy with dependency on the supervisor, the primary focus on him/herself, and high anxiety level due to working in a new area or due to the process of being evaluated.

In level 2, individuals have a fluctuating motivation such as elevated when self-reliance is high, but truncated whilst perplexity or when unenthusiastic distress has occurred, striving for farther autonomy, have high dependency-autonomy conflict and emphases more on the emotional and cognitive experiences of the supervisee. At this point, supervisors must still be supportive, appreciative, and prescriptive to the supervisee; however, a little bit of freedom and autonomy should be imposed to teach supervisee to be self-reliant and responsible. On the other hand, in level 3, fluctuations in motivation diminish; and the individual exhibits more constant behavior. Moreover, Stolenberg, Mcneill and Helsworth (1987) mentioned that there is a vaster acceptance of self strengths and weaknesses and shows countless autonomy, amplified self- and other-awareness and is better in measuring the emotional impact of others, deep knowledge and integration of learning and the supervision turn out to be more of a consultation with more academic involvement rather than intensive guidance and advice.

A mix-matched in the behavior of the supervisor may lead into the destruction of the supervisee. A supervisor who is not supportive and 
prescriptive with the supervisee will surely be resulting failure in the entire supervision process. A study conducted by Rooney (2004) that unsupportive managerial behaviors have disadvantageous effects on the psychological aspects of subordinates. Another study piloted by Mage (2003) entitled 'Leading Despite Your Boss' enlisted characteristics of an unsupportive supervisors. Some of the unfavorable characteristics embrace: deficient strong prospective, retracting judgments, integrity issues, involvement deleterious politics and poor in supervisory activities. However, through an integrated model focusing on the support related behavior showed by the managers in a specific institution, outcomes have been positive and initiated better changes in the organization. This is evidence that behavior of the supervisor have significant relationship toward achieving success rate of producing competent employees (Rooney \& Gottlieb, 2009).

Glickman et al (1995) stated 'Instructional supervision is the function in educational systems that draws together the discrete elements of instructional effectiveness into a whole educational action' (p. 15). Therefore, an effective and efficient development model like IDM would be impeccable to achieve an excellent educational system because IDM embraces the three essential components: supervision, teaching, and learning as postulated by Montgomery (1999).

The main role of the instructional supervisor in the IDM is to provide assistance to the supervisee in transforming to novice to master professional. Glickman et al (2001) categorized provision of assistance into three classes: (1) directive, (2) collaborative, and (3) non-directive. The supervisor plays the most important role in the directive supervision process because it generates the goals and objectives for the supervisee for lacking the expertise, skills, conceptual thinking and commitment. Moderate conceptual thinking and abstracting form the teacher's part must be partnered with collaborative assistance from the supervisor. This means that both of them should be involved in the planning and establishing of goals and objectives and how they will achieve it. Non-directive assistance goes with supervisee who has high conceptual thinking, skills and competencies, and commitment. The supervisor gives his trust and confidence to the supervisee on how to achieve the set goals and objectives; likewise, passive supervisory activities are necessary for this kind of process.

The main ingredients to have a successful IDM or in any development models of instructional supervision towards identifying the level of the supervisee's development through various assessment methods and strategies and recognize the appropriate behavior of the instructional supervisors. Glickman et al (2001) added that instructional leaders must employ the following learning activities to keep the supervisory process in 
the loop: active listening, encouraging, reflecting, problem solving and critical thinking.

There is no perfect model of supervision, however, it is case-to-case basis conforming to actual situation of the setting. IDM has shown and exemplified numerous advantages in the process of supervision; however, there are certain disadvantages that need to be resolved by conducting further studies to modify these threats into opportunities. According to Haynes et al (2003) the major concern of IDM is solely benefitting the supervisee rather than the supervisor due to its diminutive application in the post-graduate supervision. Similarly, there are inadequate methods and strategies that will pilot the supervisory processes. However, due to empirical research conducted by some leading proponents of the development models of supervision, Ronnestad and Skovholt (1993; 2003) constructed a model that would mitigate the first shortcoming of the IDM. The Ronnestad and Skovholt's model focuses not only with the supervisee rather than welfare of the supervisor. They believed that supervisor development is a complex process rather than simplistic that needs continuous reflection. Ronnested and Skovholt (2003) postulated that "a close and reciprocal relationship between how counselors/therapists handle challenges and difficulties in the client relationship and experiences of professional growth or stagnation" ( $p$. 40).

Lastly, there are numerous models that would work for instructional supervision such as the clinical, contextual, conceptual, differential, and/or combinations of all like the Supervisory Options for Instructional Leaders (SOIL) Model that can both benefit the supervisor and supervisee (Fritz \& Miller, 2003). Supervisory models do not limit the interaction and activities of the relationship between the supervisor and supervisees and process rather it opens doors for assortment of opportunities that can enrich the learning development of both parties.

\section{Conclusion:}

Integrated Development Model of Supervision (IDM) has a strong foundation to be an effective framework and platform for instructional supervision. As discussed in the previous texts, it showcases a dynamical process of learning and development between the supervisor and supervisee, thus, achieving its goal to make the supervisee attain a status from novice to a master professional. The proponent of the IDM made sure that supervisors would have appropriate guidance through strategies, interventions, and methods of supervision that promotes continuous growth and development. Thus, it also explores on how to prevent and resolve diversity issues at all cost. 


\section{References:}

Anonymous. IDM Supervision: An Integrated Development Model for Supervising Counselors and Therapists. Adolescence, 36. 141: 184-185. http://search.proquest.com/docview/195933180/B0633B7E627F4AF1PQ/1? accountid $=38643$

Bernard, J.M, \& Goodyear, R.K. (1992). Fundamentals of Clinical Supervision. Boston: Allyn \& Bacon.

Chagnon, J., \& Russell, R. (1995). Assessment of Supervisee Developmental Level and Supervision Environment Across Supervisor Experience. Journal of Counseling and Development, 73 (5), 553-558. DOI: 10.1002/j.15566676.1995.tb01793.x

Fritz, C., \& Miller, G., (2003). Supervisory Options for Instructional Leaders in Education. Journal of Leadership Education, 2 (2), 13-27.

Glickman, C.D., Gordon, S. P., \& Ross-Gordon, J. M. (2001). Supervision and Instructional Leadership ( $5^{\text {th }}$ ed.). Needham Heights, MA: Ailyn \& Bacon.

Haynes, R. Corey, G. \& Moulton, P. (2003). Clinical Supervision in the Helping Professions: A Practical Guide. Pacific Grove, CA: Brooks/Cole.

Holloway, E. L. (1992). Supervision: A Way of Teaching and Learning. In S. D. Brown \& R. W. Lent (Eds.), Handbook of Clinical Psychology $\left(2^{\text {nd }}\right.$ ed., pp. 177-214). New York: Wiley.

Littrell, J., Lee-Boden, N., \& Lorenz, J. (1979). A Development Framework for Counseling Supervision. Counselor Education and Supervision, 19, 129136.

Loganbill, C., Hardy, E., \& Delworth, U. (1982). Supervision: A Conceptual Model. The Counseling Psychologist, 10 (I), 3-42.

Mage, G. C. (2003). Leading Despite Your Boss. HR Magazine, 48, 9, 114139.

Montgomery, D. (1999). Positive Teacher Appraisal Through Classroom Observation. London: David Fulton.

Ronnestad, M. H. \& Skovolt, T. M. (1993). Supervision of Beginning and Advanced Graduate Students of Counseling and Psychotherapy. Journal of Counseling and Development, 71, 396-405.

Rooney, J. (2004). Supportive and Unsupportive Managerial Behaviors: Typology, Validation, and Psychological Effects on Subordinates. University of Guelph (Canada). ProQuest Dissertation Publishing. NQ92915.

Rooney, J. \& Gottlieb, B. (2009). How Support-Related Managerial Behaviors Influence Employees: An Integrated Model. Journal of Managerial Psychology, 24, 5, 410-427.

Russel, R.K., Crimmings, A.M., \& Lent, R.W. (1984). Counselor Training and Supervision: Theory and Research. In S. D. Brown \& R. W. Lent (Eds.), Handbook of Clinical Psychology ( ${ }^{\text {nd }}$ ed., pp. 625-681). New York: Wiley. 
Skovolt, T.M., \& Ronnestad, M.H. (1992). The Evolving Professional Self: Stages and Themes in the Therapist and Counselor Development. Chichester, England: Wiley.

Stoltenberg, C. D. (1981). Approaching Supervision from a Developmental Perspective: The Counselor Complexity Model. Journal of Counseling Psychology, 28 (1), 59-65.

Stoltenberg, C. D. (1993). Supervising Consultants in Training: An Application of a Model of Supervision. Journal of Counseling \& Development, 72, 131-138.

Stoltenberg, C. D. \& Delsworth, U. (1988). Developmental Models of Supervision: It is Development-Response to Holloway. Professional Psychology: Research and Practice, 19 (2), 134-137.

Stoltenberg, C. D, \& McNeill, B. W. (2010). IDM Supervision: An Integrated Developmental Model for Supervising Counselors and Therapists. East Sussex: Routledge, Taylor \& Francis Group.

Stoltenberg, C. D., Mcneil, B.W, \& Delsworth, U. (1997). IDM: The Integrated Development Model of Clinical Supervision. San Francisco: Jossey-Bass.

Taces Presents (2009). The Development Model. Supervision, Theories, Methods, and Ethics. https://www.txca.org/images/tca/TheoriesofSupervision/TheoriesofSupervisi on9.html 